\title{
Aikuiskoulutuksen johtoryhmän esitysten toteutuminen
}

Aikuiskoulutuksen johtoryhmä jätti viiden vuoden työn tuloksena mietinnön keväällä 1985. Johtoryhmä esitti siinä aikuiskoulutuksen kehittämiseksi eritasoisia jatkotoimenpiteitä ja jakoi nämä ajallisesti kahteen vaiheeseen. Ensimmäiseen vaiheeseen sijoitettiin toimenpiteet, jotka on valmisteltu niin pitkälle, että ne voidaan panna toimeen välittömästi, tai niiden valmistelun arvioidaan kestävän korkeintaan kaksi vuotta. Toiseen vaiheeseen sijoitettiin ehdotukset, joiden valmistelu kestää yli kaksi vuotta.

Opetusministeriön avuksi asetettiin vuoden 1985 alusta aikuiskoulutusneuvosto pysyväisluonteiseksi asiantuntijaelimeksi. Vastuu aikuiskoulutuksen kehittämiseksi siirrettiin aikuiskoulutusneuvostolle ja linjahallinnolle. Nyt kun on kaksi vuotta kulunut aikuiskoulutuksen johtoryhmän mietinnön ilmestymisestä, on sopiva aika tarkastella, mitkä esitykset on toteutettu. Yleisenä huomiona voidaan todeta, että pääosa johtoryhmän tekemistä kiireellisistä toimenpide-esityksistä on toteutettu. Aikuiskoulutuksessa on tehty jatkuvaa hiljaista kehittämistyötä kuluneen kahden vuoden aikana. Eräiden laajojen toiseen vaiheeseen kuuluvien ehdotusten toteuttamisessa ei kuitenkaan ole juuri edetty. Näitä ovat $\mathrm{mm}$. monimuoto-opetuksen periaatteen läpivienti käytäntöön, aikuisten yleisen tutkintojärjestelmän luominen ja aikuisopintojęn neuvonta- ja ohjauspalvelujen systemaattinen järjestäminen. Olemme kuitenkin selvästi tulemassa tilanteeseen, jossa tarvitsemme uusia tavoitteita aikuiskoulutuksen kehittämiseksi.

Aikuiskoulutusneuvosto päättikin osin tämän havainnon johdosta valmistella Aikuiskoulutuksen kehittäminen 1988-1990 -suunnitelman oman kolmivuotiskautensa päätteekși. Aikuiskoulutuksen suuret kehittämislinjat näyttävät entistä selvemmin liittyvän työelämän aikuiskoulutuskysymyksiin. Niiden ratkaisuissa joudutaan keskustelemaan työelämän koulutuksen tarjontajärjestelmän luomisesta ja rahoittamisesta, osallistumisjärjestelmästä sekä opiskelijoiden toimeentulosta. Tätä ongelmatiikkaa valotti selvästi Aikuiskasvatuslehdessä (1-2/1987) ollut ylijohtaja Mela- metsän artikkeli ammatillisen aikuiskoulutuksen rahoittamisesta.

Seuraavassa esitellään luettelomaisesti aikuiskoulutuksen johtoryhmän esitysten ajankohtainen toteutumistilanne. Kehittämisesitykset ovat aikuiskoulutuksen johtoryhmän (KM 1985:36) mietinnössä esitetyn jaottelun mukaisessa järjestyksessä.

\section{Ensimmäinen} toteutumisvaihe

\section{Aikuiskoulutuksen yleinen kehittäminen}

\subsection{Opintovapaalain uudistaminen}

Nykytila: Opintovapaalaki (L 663/86) on uudistettuna tullut voimaan 1.1.87 alkaen. Opintovapaata voi saada viiden vuoden aikana yhteensä kaksi vuotta.

Jatkotoimet: Muutoshankkeita ei ole vireillä.

1.2 Opintotukilainsäädännön uudistaminen aikuisten opintososiaalisen toimikunnan esityksen mukaisesti

Nykytila: Aikuisopintojen rahoitustyöryhmä (1985:41) ehdotti opintotukilain muuttamista siten, että aikuisopintorahaa koskeva kokeilu voidaan järjestää vuosina 198789.

Jatkotoimet: Opintotukilain muutos on hyväksytty keväällä 1987 . Aikuisopintorahakokeilu käynnistyy 12 miljoonan markan määrärahan turvin syksyllä 1987 . Vuodelle 1988 esitetään 30 miljoonan markan määrärahaa. Opetusministeriö on asettanut aikuisopintotuen seuraamiseksi työryhmän. Työryhmän määräaika päättyy 30.9.1990.

1.3. Työttömyysturvan perusteiden muuttaminén niin, että työmarkkinoiden käytettävissä oleva henkilö voi tukeaan menettämättä osallistua muuhunkin kuin työllisyyskoulutukseen. 
Nykytila: Muutos toteutettiin vuoden 1987 budjetissa siten, että 500 henkilöä voidaan kouluttaa työllisyyskoulutuksen eduin muussakin ammatillisessa koulutuksessa kuin työllisyyskoulutuksessa.

Jatkotoimet: Muutosta ryhdytään toteuttamaan syksystä 1987 alkaen.

1.4 Keski- ja korkea-asteen valintajärjestelmien muuttaminen siten, että aikaisempi koulutus tai työ- ja muu elämänkokemus otetaan valinnassa huomioon.

Nykytila: Valtioneuvosto on antanut päätöksen yhteisvalinnan perusteiden uudistamisesta (22.5.1986). $\mathrm{AKH}$ on tämän pohjalta vahvistanut uudet yhteisvalinnan valintaperusteet vuodelle 1987. Valintaperusteet ottavat entistä paremmin huomioon työ- ja muun elämänkokemuksen sekä mahdollistavat ns. joustavan valinnan suorittamisen ohi pistemäärien mm. näillä perusteilla.

1.5 Aikuiskoulutustilastoinnin kehittäminen vuoden 1986 alusta lukien Tilastokeskuksen ja opetushallinnon yhteistyönä.

Nykytila: Korkeakoulujen täydennyskoulutuksen ja avoimen korkeakoulun tilastointia on toteutettu kokeilunluontoisesti. Vuodesta 1988 alkaen tämä on muuttumassa pysyväksi osaksi korkeakoulutilastointia.

Jatkotoimet: Seuraavaksi ryhdytään suunnittelemaan ammatillisten oppilaitosten kurssitilastointia.

1.6. Aikuisopintojen tutkintojärjestelmien kehittäminen. Tehtävä on kolmiosainen:

1. Tarkistetaan yleissivistävän koulutuksen tutkintojärjestelmiä peruskoulu- ja lukiotasolla.

2. Turvataan aikuisopiskelijoiden mahdollisuudet suorittaa tutkintoja samaan tapaan kuin mitä Aikuisopintojen Tutkintotoimikunta on tehnyt.

3. Aikuisten ammatillisen koulutuksen tutkintojärjestelmän suunnittelu.

Nykytila: - Jatkuvan koulutuksen projektiryhmä jätti (13.12.1985/1986:1) muistionsa. Työryhmä määritteli tutkintojärjestelmän kehittämisen periaatteita. Lisäksi työryhmä esitti opetusministeriön avuksi perustettavaksi tutkintoasiain neuvottelukuntaa vuoden 1986 aikana.

— AKH:n hyväksymässä amma- tillisen aikuiskoulutuksen kokeiluohjelmassa on mukana aineksia tutkintojärjestelmän kehittämiseksi.

Jatkotoimet: - Tutkintoasiainneuvottelukuntaa ei ole asetettu.

- Uudessa ammatillisen koulutuksen lainsäädännössä on oppilaitoksen velvollisuudeksi asetettu yksityisoppilaiden otto.

- Oikeutta osallistua ylioppilastutkintoon ollaan laajentamassa keskiasteen tutkinnon suorittaneisiin.

- Neuvoston ammatillisen koulutuksen jaosto on valmistellut esitystä tutkintojärjestelmän kokeiluksi.

1.7. Monimuoto-opetukseen soveltuvan oppimateriaalin kehittäminen

Nykytila: Monimuoto-opetuksen työryhmä (1986:39) esitti myös opiskeluaineiston tuottamista. Tällä hetkellä opiskeluaineistoa tuotetaan eräissä yksittäisissä oppilaitoksissa. Keskitetty monimuoto-opetukseen perustuva oppimateriaalin tuottaminen ei ole käynnissä.

1.8. Yleissivistävää pohjakoulutusta täydentävä kirjeopetus on saatettava lakisääteisen valtionavun piiriin.

Nykytila: Ei ole toteutunu. Myös monimuoto-opetuksen työryhmä esitti kirjeopetuslain 1 §:n muuttamista tältä osin.

Jatkotoimet: Valtion tulo- ja menoarviossa oli ensimmaisen kerran vuonna 1986 harkinnanvarainen määräraha asiaa varten.

1.9. Ammatillisen aikuiskoulutuksen ensimmäinen kokeiluohjelma tulisi laajentaa tarpeellisiksi katsotuille aloille.

Nykytila: - Kokeiluohjelma käynnistyi varsinaisesti 1985. Tällä hetkellä on käynnissä tai jo loppuunviety 10 eri kokeilua.

- Lisäksi on käynnissä Lapin (LAIKO) ja Kainuun työllisyyttä edistävät aikuiskoulutuskokeilut.

Kokeiluohjelma hyväksytään vuosittain.

Jatkotoimet: Määrärahojen niukkuus haittaa kokeiluohjelman toteuttamista ja laajentamista.

1.10. Ammatillisten oppilaitosten kurssiosastojen ja iltalinjojen perustamisen tulee perustua tarveselvityksiin. 
Nykytila: Lääninhallitukset laativat v. 1985 suunnitelman kurssiosastojen perustamisesta ammatillisiin oppilaitoksiin. Tuolloin eri alojen kurssiosastohankkeet asetettiin myös tärkeysjärjestykseen. AKH on tämän pohjalta hyväksynyt KTS:n käsittelyn yhteydessä kurssiosastojen perustamissuunnitelman.

- Ammatillisiin oppilaitoksiin perustettiin 13 kurssiosaston johtajan virkaa v. 1986 ja 14 virkaa v. 1987.

Jatkotoimet: - Opetusministeriön KTS:n mukaan tullaan ammatillisiin oppilaitoksiin perustamaan vähintään 20 uutta aikuiskoulutusosastoa/ kurssiosastoa vv. 1988-92.

- Tavoitteena on, että vuoteen 1990 mennessä aikuisten ammatillisen peruskoulutuksen vakinaiset aloituspaikat nostetaan 3000:een ja vuoteen 1992 mennessä 5000:een.

1.11. Hallinnon eri tasoilla tulee olla riittävä määrä henkilöstöä.

Nykytila: Hallinnon hajauttamiskomitea on esittänyt perusteellista opetusministeriön, keskusvirastojen ja lääninhallitusten välisen työjaon tarkistamista.

Jatkotoimet: Valtioneuvosto antoi vuonna 1986 periaatepäätöksen tämän suunnittelutyön jatkamisesta.

1.12. Aikuiskoulutuksen kehittämismäärärahojen tuntuva nostaminen.

Nykytila: Aikuiskoulutuksen kehittämismäärärahat eivät ole viimevuosina kasvaneet. Uutta on Lapin alueellinen työllisyyttä edistävä aikuiskoulutuskokeilu.

Jatkotoimet: Aikuiskoulutusneuvosto nosti tämän asian toiseksi keskeiseksi budjettitavoitteekseen. Neuvosto esittää aikuiskoulutukselle omaa kehittämis-, kokeilu- ja tutkimusmomenttia ja sille 20 miljoonan markan määrärahaa. Valtion tulo- ja menoarviossa vuodelle 1988 perustettiin uusi aikuiskoulutuksen kokeilumomentti. Määrärahaa esitetään 3,9 miljoonaa.

1.13. Opintoneuvonnan ja tietopalveluiden tehostaminen

Nykytila: Asiaa ei ole tehostettu kovin järjestelmällisesti. Paikallisesti, alueellisesti ja monilta koulutusa- loilta on laadittu erilaisia aikuiskoulutusoppaita. Työvoimahallinnon tietopalvelu ja kirjastolaitos ovat keskeiset ohjaus- ja tietopalvelulaitokset.

Jatkotoimet: Keskitettyä aikuisväestön opintoneuvonnan ja tietopalvelun tehostamissuunnitelman laadintaa ei ole vireillä.

\section{Ammatillinen aikuiskoulutus}

2.1. Ammatillisen aikuiskoulutuksen kehittämisessä on syytä noudattaa integroinnin ja toimintakohtaisuuden periaatteita

Nykytila: Ammattikasvatushallitus suorittaa nykyään kurssitoiminnan suunnittelun oppilaitosmuodoittain. Päätösvaltaa kurssien käynnistämisessä ja opetussuunnitelmien hyväksymisessä on siirretty oppilaitoksille.

2.2. Ammattikasvatusneuvostoon muodostetaan toimialakohtaisia jaostoja.

Nykytila: - Pätevyys- ja neuvottelukuntatyöryhmä (1986:30 esitti I osamuistiossaan, että ammattikasvatusneuvoston alakohtaișet jaostot asetetaan koulutusaloittain nykyisen oppilaitosryhmittäisen jaottelun sijasta.

- Muutosta ei ole toteutettu.

2.3. Ammattikasvatushallituksen aikuiskoulutuksen henkilöstövoimavaroja tulee lisätä.

Nykytila: Ammattikasvatushallituksen ammattikurssi- ja oppisopimusasiaintoimistossa työskentelee toimistopäällikön lisäksi 19 henkilöä ja tarkastustoimistossa työskentelee 12 henkilöä ammatillisiin kurssikeskuksiin ja työllisyyskoulutukseen liittyvissä tehtävissä. Opetussuunnitelma- ja oppimateriaalitoimistoihin on palkattu kumpaankin yksi suunnittelija aikuiskoulutustehtäviin. Lisäksi eri opetustoimistoissa ja AKH:n muissa toimistoissa yhdelle tai useammalle virkamiehelle kuuluu aikuiskoulutusasiat osana virkatehtäviä.

\subsection{Yksityisoppilasjärjestelmän kehittäminen}

Nykytila: — Vuonna 1987 hyväksytty laki ammatillisista oppilaitoksista säätää (22 §), että oppilaitoksella on velvollisuus ottaa yksityisoppilaita. 
—.Vuonna 1985 ammatillisissa oppilaitoksissa opiskeli noin 1000 yksityisoppilasta.

Jatkotoimet: - Opetusministeriön KTS:n mukaan yksityisoppilaiden määrälliseksi tavoitteeksi vuoteen 1992 mennessä asetetaan noin 3000 yksityisoppilasta.

- Opiskelumahdollisuuksia kehitetään siten, että yksityisoppilailla on mahdollisuus saada oppilaitoksen taholta tukea opinnoilleen ja osallistua tietyissä tilanteissa lähiopetukseen.

2.5. Työllisyyskoulutuksen alueellisen suunnittelun kehittäminen ja opetusministeriön ja työvoimaministeriön välisen työnjaon selkiyttäminen

Nykytila: - Työllisyyskoulutuksessa on kolmessa läänissä ollut alueellinen työllisyyskoulutuksen päätösvallan delegointikokeilu vuodesta 1985 lähtien.

- Ammatillisten kurssikeskusten kehittämistä varten asetettiin 3.4.1987 toimikunta, jonka määräaika on vuoden 1987 loppuun. - Valtioneuvoston periaatepäätös ammatillisen aikuiskoulutuksen rahoittamisen suunnitteluperiaatteista määrittelee opetusministeriön ja työvoimaministeriön välistä työnjakoa työllisyyskoulutuksessa.

\section{Yleissivistävän pohjakoulutuksen täydentäminen}

3.1. Iltalukioiden uudistaminen siten, että opiskelijat voivat käyttää itseopiskelua tukevia ratkaisuja.

Nykytila: Iltalukiolaki (L 478/83) tuli voimaan 1.8.1985. Lain 9 §:n mukaan osa iltalukioiden opetuksesta voidaan antaa etäopetuksena.

3.2. Kirjeopetuksesta aiheutuvat kustannukset tulee lukea lähiopetusta antavan oppilaitoksen valtionosuuteen oikeuttavaksi kustannukseksi.

Nykytila: Katso kohtaa 3.1.

Ammatillisen koulutuksen osalta on kirjeopetuksesta ja -opiskelusta annetun lain perusteella valtionavun osuus ammatillisessa kirjeopetuksessa 60 \% hyväksyttävistä kustannuksista. Nykyi- sin määräraha on riittänyt noin $20 \%$ :n valtionapuun.

Jatkotoimet: Opetusministeriön KTS:n mukaan liikealan erikoisoppilaitosten yhteydessä toimivien kirjeoppilaitosten toiminnan yhdistämistä pääoppilaitoksen yhteyteen selvitetään.

\section{Vapaa sivistystyö}

4.1. Kansalais- ja työväenopistojen valtionapulainsäädäntö tulee uudistaa siltä osin kuin se on ristiriidassa kunnallislain kanssa.

Nykytila: Lakia kansalais- ja työväenopistoista on muutettu 1.8 .85 voimaan tulleella lailla (642/85).

4.2. Opintokeskuslain ns. pikatarkastus

Nykytila: Opintokeskusten valtionavusta annettua lakia on muutettu 1.7.1986 voimaan tulleella lailla (966/1985).

4.3. Järjestöllistä sivistystyötä koskevat selvitykset on pantava vireille.

Nykytila: Järjestöllisen sivistystyön valtionaputyöryhmä (1987:13) on tehnyt ehdotuksen laiksi eräiden sivistysjärjestöjen valtionavusta.

\section{Toinen toteutusvaihe}

5.1. Opintotukilainsäädäntö on uudistettava toimikunnan ehdottamalla tavalla.

Nykytila: Katso kohtia 1.1. ja 1.2.

Jatkotoimet: Aikuisopintotuen seuraamiseksi asetetun työryhmän tehtävänä on tehdä 30.9.1990 mennessä ehdotus pysyvästä aikuisopintojärjestelmästä ja sen rahoituksesta.

5.2. Aikuskoulutuksen neuvonta- ja tiedotuspalveluverkoston luominen. Vastuu-, koordinaatio- ja työnjakokysymysten selkiyttäminen.

Nykytila: Katso kohtaa 1.13 .

5.3. Koulutustarpeen arvioinnin tulee olla jatkuvaa

Nykytila: Opetusministerön apuna toimiva koulutussuunnittelun neuvottelukunta arvioi ammatillisen keskija korkea-asteen koulutuksen tarvetta tällä hetkellä vuoteen 2000 asti. Tämän vuoden lopussa valmistuvassa mietinnössä on tarkoitus käsitellä myös ammatillisen aikuiskoulutuksen tarvetta. 
Jatkotoimet: Erityisesti lyhytkestoisen aikuiskoulutuksen tarvearviointi siirtyy entistä enemmän alue- ja paikallistason vastuulle mm. koulutuksen uusien rahoitusratkaisujen johdosta.

5.4. Kansalais- ja työväenopistojen osalta on ryhdyttävä siihen valmistelutyöhön, jota valtionosuuslainsäädäntö ja muu toiminnallinen kehittäminen edellyttävät.

Nykytila: Kansalais- ja työväenopistoja koskevaa lainsäädännön kokonaisuudistusta ei ole pantu vireille.
5.5. Järjestöllisen sivistystyön toimikunnan pohjalta laadittujen lisäselvitysten edellyttämien toimenpiteiden toteuttaminen.

Nykytila: Katso kohtaa 4.3.

5.6. Ammatillisen aikuiskoulutuksen kelpoisuutta tuottamattomien tutkintojen mahdollinen niveltäminen yleiseen koulutus- ja tutkintojärjestelmään.

Nykytila: Ammattikasvatushallituksen hyväksymään aikuiskoulutuksen kokeiluohjelmaan sisältyy kokeilu työteknikkojen kouluttamisesta teknikoiksi. Muilta osin ei ole toteutunut. 